\title{
Representasi Realitas Dunia Pop Art Warhol Sebuah Tinjauan Semiologi
}

\author{
Baskoro Suryo Banindro \\ Program Studi Desain Komunikasi Visual, Jurusan Desain \\ FSR ISI Yogyakarta \\ banindro@gmail.com
}

\begin{abstract}
This study is the result of a pre-discussion on the meaning of Andy Warhol's printmaking object material. The purpose of this study is to obtain an outline of the description of the reality and myths in Warhol's work. Data is obtained from visual objects in the field and relevant literature studies, then descriptively will be analyzed by Danesi, semiological approach. The results of this study concluded that through printmaking's pop art work, Warhol wanted to build an ideology perpetuated by the dominant forces in society.
\end{abstract}

Keywords: Warhol, pop art graphic art, ideology

\section{LATAR BELAKANG MASALAH}

Sejak seorang seniman Amerika bernama Andy Warhol memperkenalkan printmaking dengan gambar kaleng kacang dan minuman sebagai objeknya, maka apa yang disebut era modern pop art dimulai. Pembaruan seni gaya Warhol mempunyai implikasi lain yakni komodifikasi yang berasal dari dua akar kata berbeda: "komoditas" dan "modifiaksi", menurut istilah yang lazim dipakai dalam kajian budaya, yaitu proses yang diasosiasikan dengan kapitalisme dimana objek kualitas dan tanda-tanda diubah menjadi komoditas yaitu sesuatau yang tujuan utamanya terjual di pasar (Barker, 2005, 517). Sebagai contoh T-shirt dengan muka gambar Che Guevara melekat di tubuh anak-anak muda, atau wajah John Lennon yang dijadikan ikon salah satu tas distro. Juga produk hot print wajah Mao Zedong yang gemar dipakai oleh merekamereka yang sangat mungkin belum pernah mendengar Revolusi Kebudayaan di Cina.
Pada masa-masa kemunculan perdananya banyak kalangan yang beranggapan bahwa karya pop adalah karya yang tidak memiliki nilai estetik dan hanya sebuah karya yang diciptakan untuk kesenangan belaka. Tapi disamping itu pula orang yang beranggapan bahwa karya pop adalah sebuah karya yang tercipta dari kebebasan berekspresi dan membuktikan bahwa tidak ada diskriminasi dalam seni. Bahkan ada yang beranggapan bahwa dengan karya pop, masyarakat diajak untuk lebih objektif dalam melihat sebuah karya.

Karya printmaking Warhol mengambil tema variatif mulai dari sekuntum bunga, kepala sapi, korban kecelakaan, bintang Hollywood seperti close up wajah Marylin Monroe, Jim Morisson, menjadi icon populer dan abadi hingga saat ini, ribuan karyanya menjadi koleksi para kolektor, museum manapun, juga galeri seni. Bagaimanakah dunia seni Warhol dan bagaimana pula 
masyarakat membaca dan memahami karyanya?

\section{Andy Warhol}

Warhol yang lahir di Pittsburgh, Pensylvania USA, dengan nama asli Andrew Warhola pada tanggal 6 Agustus 1928 dan meninggal di New York pada tanggal 22 Februari 1987 mempunyai talenta itu. Ia merupakan seorang seniman, sutradara avantgrade, penulis dan figur sosial Amerika. Warhol juga bekerja sebagai penerbit, produser rekaman dan actor. Dengan latar belakang dan pengalamnanya dalam seni komersial - graphic art commerce (Bockris, 1989). Warhol menjadi salah satu pencetus gerakan pop art di Amerika Serikat pada tahun 1950an, suatu tempo yang bernada I'spriit de I'age. Sebuah gerakan secara luas juga ditafsirkan sebagai suatu reaksi dan ekspresi dari gagasan besar yang terjadi atas adanya suatu perubahan sosial yang berupaya menjembatani "mundace contemporary life and art” pengikat jurang pemisah antara duniawi dan seni (Radzinowkez, 2001).

Dengan latar belakang dan pengalamannya dalam seni komersial - graphic art commerce, Warhol menjadi seorang pencetus gerakan Pop Art tahun 1960an di Amerika, kultur yang populer akan musik, seni, desain dan literature menjadi lebih mudah diakses dan merefleksikan kehidupan seharihari. Kemunculan karya Warhol dengan seni pop penuh dengan warna, desain sederhana dan media seni yang tidak hanya di atas media kanvas, tetapi juga di atas sepatu, display komputer atau bahkan makanan kaleng, membuat karyanya terasa dekat dengan masyarakat. Berkat Warhol, hasil karya seni tidak hanya bisa dinikmati oleh kalangan berduit saja, tapi oleh semua orang.
Karya Warhol yang paling dikenal adalah printmaking (cetak saring) kemasan produk konsumen dan benda sehari-hari yang sangat sederhana dan berkontras tinggi, misalnya bunga "Poppy", dan gambar sebuah "Pisang" pada cover album pada music rock The Velvet Undergroung and Nico (1967), tokoh-tokoh mitos populer Amerika: Mickey dan juga potret-potret ikonik selebritas abad 20, seperti Elvis Persley, Jaqueline Kennedy, Onasssis, Judy Garland, dan Elizabeth Taylor. Di luar dunia seni, Warhol dikenal dengan ucapannya saat berjumpa pada reporter, "Kalimat terbaru saya adalah, "Dalam lima belas menit, semua orang akan menjadi terkenal". Suatu penyataan yang secara implisit menyatakan bahwa seorang seniman dapat dengan cepat diciptakan. Warhol memulai karirnya di tahun 1949 sebagai desainer grafis professional yang khusus merancangi iklan komersial untuk majalah fashion Glamour, Vogue dan Harper's Bazaar, dan mendapatkan sukses besar dalam karirnya yang begitu cepat dan tidak pernah dibayangkan sebelumnya (Art Magazine)

Di tahun 1952, Warhol untuk pertama kali berpameran solo memajang karya sketsa dan iklannya di Hugo gallery, New York. Demikian pula di tahun 1954 dan 1956, Warhol berpameran di Loft Gallery, New York, dimana untuk pertama kalinya Warhol memperoleh penghargaan dalam rangka ulang tahun ke 35: Annual Art Directors Club dalam kategori sebagai outstanding achievements. Sebuah keputusan besar diambil di akhir tahun 1956, sepulangnya dari perjalanan ritual berkesenian ketika mengunjungi "the great renaissance work of art" di Florence Italia, jiwanya terbakar oleh ambisi besarnya untuk menjadi seorang artis. Warhol tidak hanya melukiskan produk massa, tetepi ia juga ingin mengumpulkan hasil seni 
produk budaya. Sebagai konsekuensinya ia membangun sebuah studio di bekas sebuah pabrik di tahun 1962. Studio seninya memperkerjakan para pekerja seni untuk berkumpul dan menghasilkan tidak hanya poster dan cetakan, tetapi juga materi lain seperti sepatu yang dirancang oleh para seniman. Debut sebagai seniman dimulai tahun 1960 ketika karya seni cetaknya mengambil tema dan objek berbasis komik: Dick Tracy dan Popeye. Karya lukis kanvas antara lain "Dollar Bills" dan karya cetak saring dengan objek bintang-bintang Hollywood. Tema lukisan printingnya yang bemuatan iklan dan populer culture, menjadikan Warhol salah satu pop artis penggerak aliran pop art di Amerika, walaupun zeitgeist nya sudah terasa dimulai tahun 1950an di Inggris, dan Amerika sendiri (Robert Atkins, 1990).

\section{Semiologi}

Menurut Danesi dan Peron (2004: 24-25), sebuah tanda diinterpretasikan dalam tiga tahap: semiosis (kemampuan otak untuk mereproduksi dan memahami tanda), representasi (penggunaan tanda untuk menguhubungkan, menggambarkan, memotret, atau mereproduksi sesuatu yang dilihat, diindera, dibayangkan, atau dirasakan dalam bentuk fisik tertentu), dan signifikasi kultural (tahap produksi dan interpretasi tanda untuk memahami segala sesuatu berdasarkan konteks tertentu). Proses interpretasi tersebut menghubungkan tubuh, pikiran, dan kebudayaan sebagai sarana untuk mereproduksi dan memaknai tanda.

\section{Representasi}

Representasi mengedepankan bahasa untuk menyatakan sebuah objek secara bermakna, atau dapat juga dikatakan mempresentasikan kepada orang lain. Adapun representasi itu sendiri dapat berupa kata, gambar, sekuen, cerita, yang dapat 'mewakili' ide, emosi, fakta, dan sebagainya. Representasi sendiri dimaknai sebagai bagaimana dunia dikonstruksikan secara sosial dan disajikan kepada kita dan oleh kita di dalam pemaknaan tertentu (Barker, 2005).

Representasi juga menggantungkan diri pada tanda dan citra yang sudah ada dan dipahami secara kultural, dalam pembelajaran bahasa dan penandaan yang bermacam-macam atau sistem tekstual secara timbal balik. Melalui fungsi tanda representasi, akan 'mewakili' yang kita tahu dan mempelajari realitas (Hartley, 2010). Warhol setidaknya membawa pesan terselubung pesan dan gejolak sosial melalui representasi budaya visual printmaking.

\section{Tanda}

Adalah perwujudan sesuatu tentang objek, dapat berupa warna, isyarat, gambar mural, objek dua atau tiga dimensi, dan lain-lain yang merepresentasikan sesuatu yang lain selain dirinya. Objek perihal yang dirujuk oleh tanda dikenal sebagai referen dan citraan dari tanda tersebut disebut konsep.

Tanda merujuk kepada sesuatu dan manusia melihat sebuah tanda, dan hal itu dapat dipastikan bahwa tanda tersebut memiliki konsep, tinggal bagaimana referensi yang dimiliki seseorang dapat memberikan rujukan dan kesimpulan. Oleh sebab itu seperti apa yang dikatakan oleh Danesi bahwa tanda merupakan sesuatu yang merepresentasikan 
seseorang atau sesuatu yang lain serta memuat pandangan tertentu di dalamnya (Danesi, Marcel, \& Peron., 2004).

\section{Printmaking}

Adalah cabang seni rupa, tepatnya seni murni, printmaking (seni grafis) mencakup beragam ekspresi artistik visual, biasanya dua dimensi, yang diproduksi di permukaan datar (Britannica, 2016). Di masa lalu printmaking dikerjakan secara manual dengan tingkat kesulitan tinggi, estetika dan roh seni cetak itu sendiri tetap dipertahankan hingga hari ini.

Konsep mengenai printmaking Warhol, mampu mempersempit jurang pemisah anatara si kaya dan si miskin dengan menyamarkan batas sosial meskipun di sisi lain menyebabkan nilai investasinya menjadi rendah, Warhol dianggap menjadi patokan penting dalam praktek seni yang tidak mengkotak-kotakan antar budaya tinggi dan rendah, akan tetapi tujuan utamanya memang bukan itu, tidak semata-mata ialah nilai memorial.

\section{Pop Art}

Pop art muncul dalam perwujudannya sebagai sebuah tanda yang melahirkan sesuatu yang terjadi di masyarakat. Seni pop art adalah salah satu bentuk genre yang merefleksikan dampak dunia industri periklanan akan kesadaran berkesenian (Berger, 2005). Di kala generasi muda Amerika Serikat mencoba mencari jati diri antara tahun 1968 - 1969, kemunculan kebudayaan pop tidak lepas dari "perjuangan" mereka melalui "pemberontakan" terhadap kemapanan dan menentang perang Vietnam, yang mencapi puncaknya di pertengahan tahun 1970an atau yang lebih dikenal dengan Flower Generation (Rusbiantoro, 2008). Dengan sengaja dan jelas,
Pop art berkembang sebagai sebuah reaksi pelawanan terhadap seni abstrak dan pencintanya berasal dari golongan anak muda. Kultur pop menghipnotis semua orang terutama remaja diawal abad 20 ini.

Pop art yang berasal dari kata populer art merupakan sebuah aliran seni yang memanfaatkan unsur-unsur visual yang abadi media massa yang umum seperti koran, majalah, iklan, televisi atau komik yang kemudian dirangkai atau di desain kembali. Sehingga dapat dikatakan bahwa pop art sebenarnya adalah sebuah seni yang tidak asli dan baru, melainkan berasal dari karya seni yang sudah ada, yang kemudian di desain kembali atau di tata kembali. Aliran pop art muncul dan berkembang setelah modernisasi pada seni, yaitu setelah muncul konsumerisme dan budaya masa. Menggunakan unsur-unsur visual dari media massa yang sedang populer bukan berarti bahwa aliran pop art selalu up to date dan selalu berubah mengikuti perkembangan jaman. Aliran seni ini sebenarnya lebih cenderung disebut seni kontemporer.

Dalam dunia poster, perkembangan aliran seni pop art cukup menarik dan sempat menjadi trend. Poster-poster warna mencolok cukup mampu menarik perhatian masyarakat umum. Poster-poster pop art memang memiliki ciri-ciri mengunakan warna-warna komplementer, cerah, terang, dan kalaupun menggunakan foto juga menggunakan high contrast. Selain itu poster pop art juga sering menggunakan balon-balon suara seperti yang ada dalam komik serta digabung dengan headline yang menggunakan tipografi yang meliuk-liuk sehingga terkesan sulit dibaca. Dengan sengaja dan jelas, pop art berkembang sebagai sebuah reaksi perlawanan terhadap seni 
abstrak (Walker, 1980). Suatu gerakkan secara luas yang juga ditafsirkan sebagai suatu reaksi dan ekspresi gagasan besar yang terjadi atas adanya suatu perubahan di masyarakat, munculnya gerakkan itu sendiri melahirkan banyak kritik. Bahwa pop art adalah aliran "new vulgarian", "gum-chewers" and "delinquents", pop art adalah seni baru yang menerima konsepsi seni rendah dan seni komersial dimana tekniknya sendiri tidak seni atau bahkan anti seni (Hamilton, 2002).

\section{Analisis Bentuk}

Warhol dalam menciptakan setiap karyanya tentunya tidak lepas dari upaya pemenuhan seleranya. Hal itu bisa dilihat dari beberapa karya printingnya, menjadi suatu karya koleksi personal sebagai elemen estetis pengisi ruang-ruang pribadi, seperti misalnya pada karya yang berjudul "Elvis"-1964 yang dikoleksi oleh seorang kolektor New York, atau "Parrot"-1984 yang dikoleksi Wendlinghousen. Menurut Read, seni yang baik adalah "an attemp to create pleasing forms" (Croce, 1965), suatu kegiatan untuk menciptakan bentuk yang dapat memberikan kepuasan dan keindahan, seni adalah realisasi dari usaha manusia untuk menciptakan yang indah-indah, keindahan karya Warhol muncul melalui objek ikon yang dipilih, teknik cetak dan selera warnanya yang selalu kontras. Sementara itu Thomas Aquinas mengisyaratkan tiga hal untuk bisa disebut indah yaitu adanya intergritas dan perfeksi, proporsi yang tepat, adanya klaritas atau kejelasan (Merapendra, n.d.)

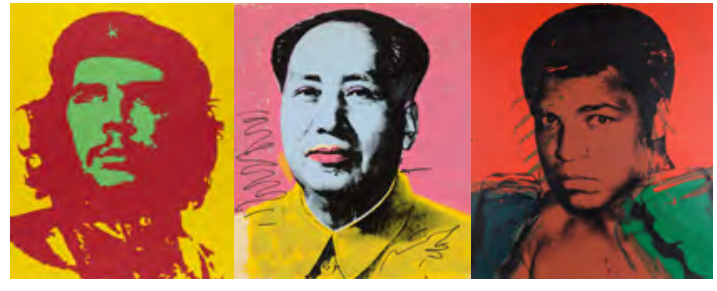

Gambar 1 Che Guevara, Mao Zedong, Moh. Ali, ikon populer semiosis, representasi signifikasi anti penindasan.

(Sumber:

https://www.pinterest.com/pin/292874781989904212/)
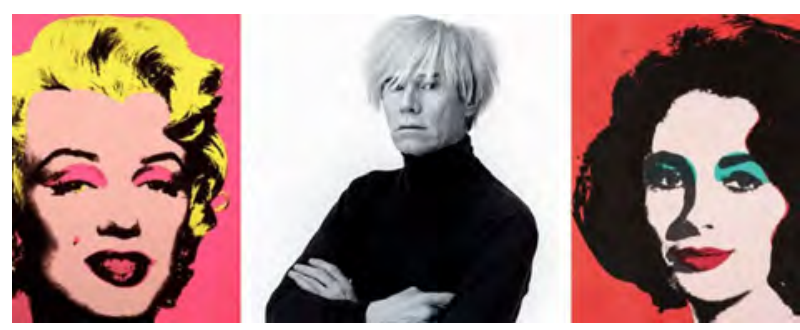

Gambar 2 Monroe, Warhol, Liz Taylor ikon populer semiosis, representasi dan signifikasi kaum borju. (Sumber:

https://www.tate.org.uk/art/artworks/warhol-lizar00320)
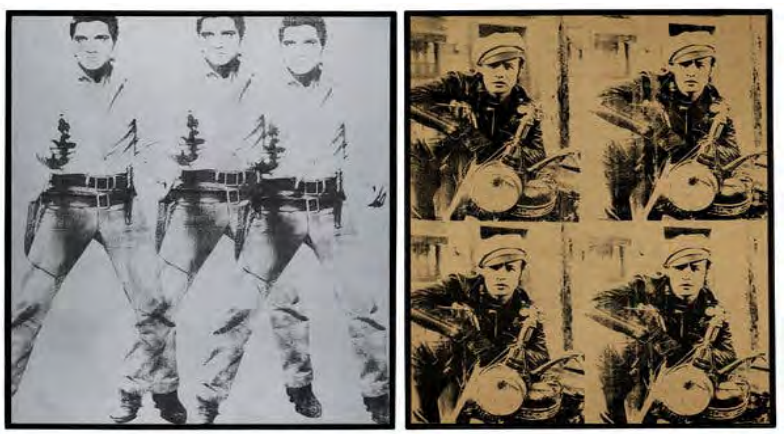

Gambar 3 'Triple Elvis'-1963 dan 'Flaming Star'. Signifikasi kultural: "an attemp to create pleasing forms" Terjual berturut-turut seharga US $\$ 81,9$ juta dan US\$ 69,6 juta.

(Sumber: https://www.businessweek.com)

Dalam karya Warhol hal ini tampak nyata melalui tata elemen visual seperti pada karya contoh 3 (tiga) dimensi kotak Brillo, Campbells Tomato Juice, Heinz Tomato Ketchup dan Del Monde. 


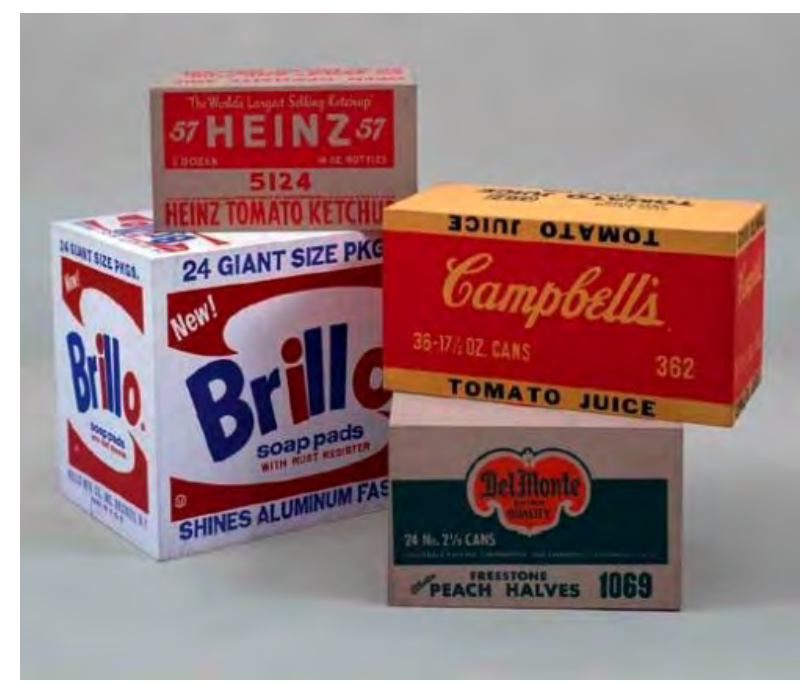

Gambar 4 Brillo, Campbells, Heinz dan Del Monte, semiosis, representasi dan signifikasi kultural American was consumers good.

(Sumber: http://wertical.com/W/daily-2/andywarholbrillo-boxes)

Menurut Feldman salah satu persyaratan sebuah karya rupa dikategorikan memenuhi fungsi sosial, apabila karya seni itu mampu mengekspresikan atau menjelaskan aspek tentang eksistensi sosial atau kolektifnya. Dalam beberapa hal karya printing Warhol merupakan representasi kondisi faktual aspek sosiologis pada jamannya, misal pada karyanya yang berjudul "Muhhamad Ali" sang black superman, petinju kelas berat era 1970-1980 yang selalu dapat mengalahkan musuhnya dengan pukulan telak knock outnya. Secara Visual keindahan karya Warhol muncul pada keselarasan atau harmonisasi pada tiap elemen rupa yang ada seperti penempatan garis, bentuk, pilihan warna, dan bidang pengisi ruang yang dikerjakan secara cermat dan presisi. Hal ini selaras dengan apa yang dikatakan Read, bahwa keindahan adalah $a$ unity of formal relations among our senseperceptions, kesatuan hubungan bentuk-bentuk yang ada di antara kesadaran personalnya, bahwa keindahan tak lain adalah kesatuan hubungan bentuk-bentuk yang ada.

Sebelum mewujudkan karyanya, Warhol biasa mengunakan pola-pola dan ukuran, hal itu menunjukkan bahwa di dalam setiap menghasilkan karya, visualisasi artistik objeknya dirancang atas kendali penuh kognitifnya, sehingga nilai keindahan dalam objeknya adalah sebuah karya oleh Read dikatakan sebagai: "benar-benar pola yang dihasilkan melalui kesadaran kita”. Seni dalam perwujudanya dapat muncul melalui kesatuan elemen rupa. Lewat penyajian visual karya, dapat dipahami makna di balik objeknya. Bentuk, istilah ini mewakili kata "Form", dan sosok mewakili kata "Shape". Keduanya hanya berbeda sedikit; bentuk biasanya mengartikan sesuatu yang lebih jelas dan dapat diejawantahkan, sedang sosok untuk sesuatu yang belum cukup jelas atau malah abstrak. Pola menurut Read adalah penyebaran garis dan warna dalam bentuk suatu ulangan tertentu, dalam sebuah karya seni. Sebuah karya seni secara garis besar oleh Read dikelompokkan ke dalam elemen irama garis, masa bentuk-bentuk, ruang, terang-gelap dan warna. Garis mempunyai "tugas" bertugas untuk memberi "bleger" (bhs:Jawa) sebuah perwujudan antara masa dan konturnya, sebagai contoh karya Warhol berjudul "Pistol", garis berperan sebagai batas kontur objek gambar sehingga tepian pistol tampak nyata. Nada adalah istilah yang digunakan dalam dunia seni rupa untuk menunjukkan pada substansi misal sebuah objek akan tampak jauh atau mendekat, atau memberi tekanan atas intesitas cahaya berbeda. Warna adalah elemen rupa yang lain, yang berfungsi untuk memberi "pernyataan keruangan", sekaligus membantu sebuah objek lukisan menjadi lebih nyata, 
warna memberi kesan efek pencahayaan dan mendimensi.

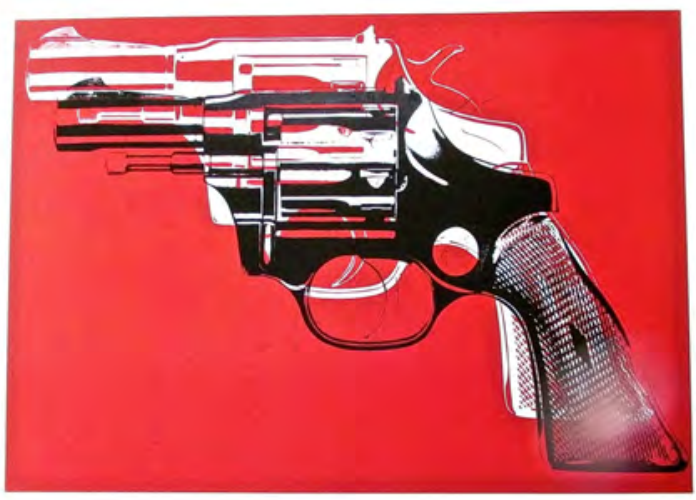

Gambar 5 Warhol menerapkan prinsip seni dan secara semiosis "benar-benar pola yang dihasilkan melalui sebuah kesadaran".

(Sumber: https://www.ebay.com/itm/Andy-WarholPoster-Pistol-Black-and-White-on-Red-BackgroundStunning)

Ikon yang efektif dapat menjalankan fungsinya secara optimal. Secara genetika ikon yang efektif memiliki ciri-ciri memiliki keterbacaan yang baik ketika diaplikasikan keberbagai ukuran sesuai kebutuhan (legible), cukup mudah diingat (memorable), sederhana dan mudah dimengerti dalam waktu relatif singkat (simple), mudah dikenali/diasosiasikan dengan konsep yang dimaksud (easily) dan dapat dibedakan dengan ikon lainnya (distinctive).

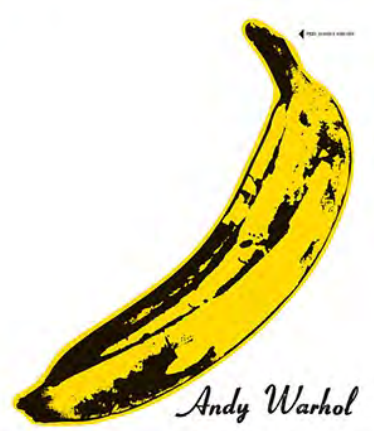

Gambar 6 The Story of Velvet Underground \& Nico Andy Warhol Cover. Semiosis yang bersifat universal. (Sumber: DailyArt Magazine)
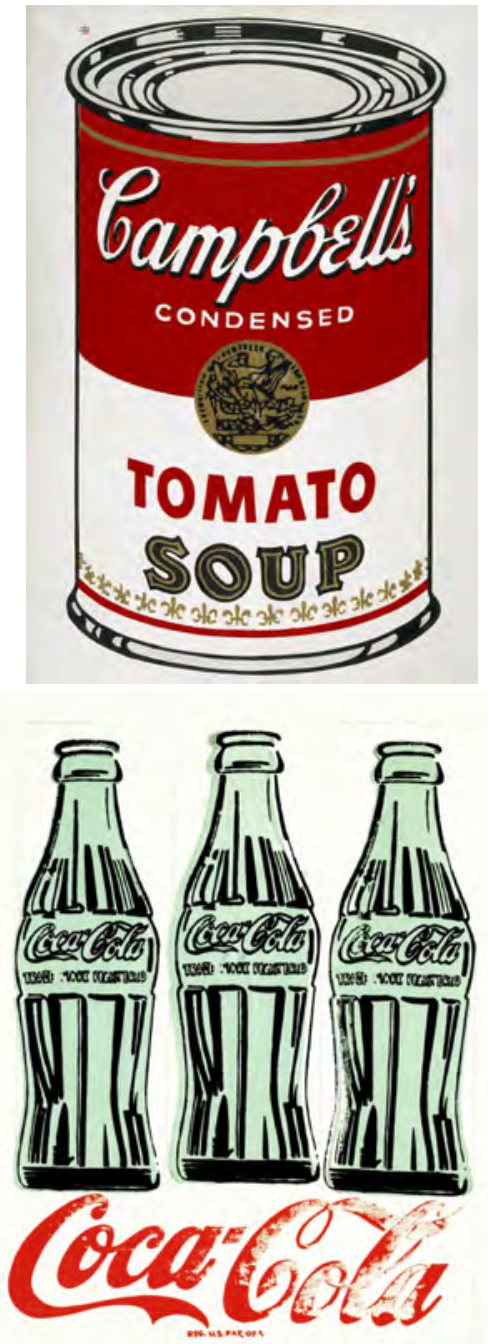

Gambar 7 Kaleng dan botol semiologi merepresentasikan dan signifikasi kultur kemakmuran sosial Amerika. (Sumber: https://www.Pintrest.com)

Gambar ikon "Pisang" di atas, secara universal akan dipersepsi secara sama di setiap tempat, sehingga dengan demikian berpotensi untuk menyampaikan pesan secara efektif. Secara khusus ikon yang efektif memiliki ciriciri yang jelas dan tidak ambigu secara grafis serta tidak bias secara linguistik, rasial, maupun kultural. Profil ikon yang tampil jelas secara grafis dan tidak menimbulkan arti semantik yang ambigu akan membuat ikon mudah dikenali, mudah ingat, dan mudah dibedakan 
dengan ikon lainnya (Lodding, 1983). Secara grafis ikon dapat tampil dalam corak abstrak, simbolik, dan realistik.

\section{Analisis Makna}

Di balik karya seni pop art Warhol, sebenarnya ia ingin merefleksi sekaligus merepresentasikan kebudayaan Amerika. Karya printmaking Warhol sangat kontekstual dalam hal hubungan penggunaan medium dengan konsep atau pesan yang ditawarkan, yang menghadirkan citra berbagai tokoh selebriti, benda dan peristiwa dalam rangkai warna-warna acid. Rangkaian karya Warhol ini menjadi begitu kuat karena merupakan kritik sosial terhadap budaya masa. Dengan jeli Warhol menggunakan medium yang lahir dari budaya tersebut, ingin menunjukkan betapa budaya populer mampu meredukasi atau bahkan mengeliminir sebuah objek dengan ramainya reproduksi sajian visual oleh media massa, sebagai refleksi akan memudarnya spirit dari masyarakat modern itu sendiri.

Printmaking Campbells Soup di atas mengambil topik salah satu produk massa yang dikonsumsi hampir oleh seluruh keluarga di Amerika. Bahwa melalui printmaking tersebut Warhol ini menunjukan empati dan dijadikan simbol "kemakmuran" bangsa Amerika. Warhol juga tertarik akan ketenaran Marilyn Monroe, menghormatinya sebagai bintang. Ia terpesona oleh kecantikannya dan pemikiranya sebagai model, melalui art printingnya, Warhol menciptakan Monroe sebagai ikon sex appeal bagi kaum pria. Sebagai simbol fetish kaum adam dan simbol liberal-kapitalis dan kebebasan berbudaya bangsa Amerika melalui visualisasi tatapan satu mata dan rona merah bibirnya.
Che dipilih sebagai simbol perlawanan dan representasi atas kuasa sebuah rezim, melalui cetak printingnya, Warhol menolak penindasan dan rasisime terhadap kaum buruh marginal pendatang di Amerika. Melalui dominasi cat printing warna merah dan hitam disertai ekspresi wajah Che-geizt, poster ini menjadi simbol perlawanan kaum muda di Amerika.

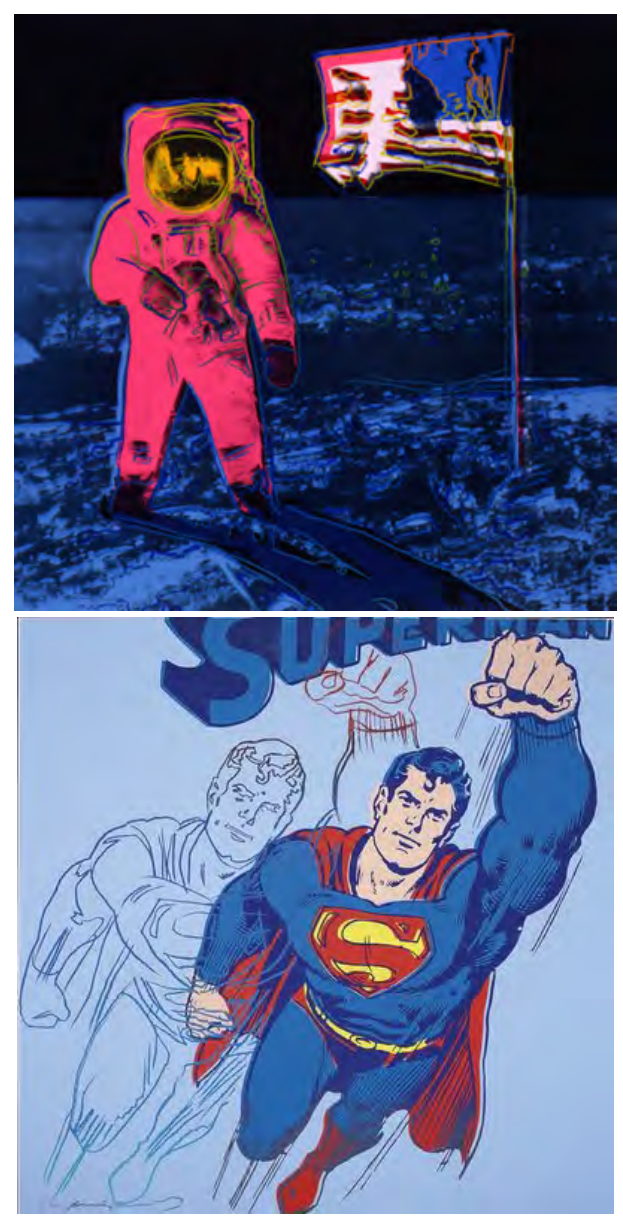

Gambar 8 Pendaratan manusia di bulan dan sosok Superman merupakan semiosis, representasi dan signifikasi kultural ultra nation. (Sumber: https://www.merdeka.com/gaya/50-karya-andywarhol-dipamerkan-di-new-york.html)

Printmaking bergambar astronot awak Apollo 11 "Lunar" yang mendarat di bulan, menjadi salah satu pilihan objeknya. Karya art printing ini sengaja dibuat Warhol untuk 
mewakili presentasi atas prestasi bangsa Amerika dalam mengejar sekaligus dapat melampaui ketertinggalan terhadap teknologi ruang angkasa Uni Sovyet "Sputnik" yang telah lebih dulu mengorbit di luar angkasa dan mempermalukan Eisenhower sebagai presiden Amerika Serikat di mata dunia.

Warhol di samping mengangkat figur yang hidup di masyarakat Amerika, juga mengambil tokoh fiksi populer "Superman" dalam komik, Warhol ingin menjadikannya sebagai presentasi sosok super hero simbol perlawanan atas kejahatan jalanan. Warhol mengambil objek budaya sehari-hari yang populer dan dibuat sebagai idiom visual. Semua orang memiliki botol Coke, dimana masyarakat yang kaya hingga miskin mampu membelinya. Melalui ikon Coca-Cola, Warhol berupaya menunjukkan salah satu "simbol kemakmuran sosial" bangsa Amerika.

Seni bisa menjadi tradisional atau inovatif; sebuah karya seni bisa jadi baru saja dibuat atau kembali ditemukan oleh orang-orang luar biasa yang kreatif atau orang-orang yang mahir dan cekatan. Para pencinta seni avant-garde secara konvensional diperkirakan memiliki tipe yang luar biasa kreatif, namun ini juga bisa terjadi pada mereka yang menerima atau kembali menemukan bentuk-bentuk seni lama yang telah dilupakan. Di dalam pengertian tertentu mereka bisa jadi menjadikan inspirasi sama seperti inspirasi yang diperoleh oleh "para penemu masalah" (Zolberg, 1990).

Setelah menyatakan berhenti sebagai seniman komersial di tahun 1956, Warhol mempersiapkan diri menjadi artis profesional. Sikap itu ditunjukannya ketika ditahun 1962, untuk pertama kalinya melakukan pameran dan bekerjasama dengan Ferus Gallery Los Angeles. Karya lukis Campbell's Soup tins sebanyak 36 buah terjual habis. Hingga tahun 1964, Warhol telah menghasilkan lebih 2.000 lembar karya cetak seni dan 5 (lima) kali ekshibisi, salah satunya dipertengahan tahun 1964, untuk pertama kalinya Warhol melakukan pameran solonya di Eropa tepatnya di Sonnabend Gallery, Paris.

\section{Kajian Sosiologis}

Peran museum, galeri dan negara sebagai penyangga art world tidak lepas dari realitas khas negerinya, di mana kapitalisme membentuk relasi imigran dari berbagai bangsa. Bukan agama dan etnik yang mempengaruhi ikatan sosial khas Amerika, melainkan kapitalisme. Perbedaan budaya digeser dari antar suku, bangsa, dan agama, ke perbedaan selera produk konsumsi. Sehingga semua itu memunculkan sistem sosial kolektif. Masyarakat penyangga merupakan support bagi seniman terkait dengan system sosial kolektif. Art world Warhol ialah para pecinta seni dan pengagumnya. Kolektor tetapnya antara lain Rudolf Nureyev, Jamie Wyeth, Mrs. Douglas Auchincloss dan Jimmy Carter mantan Presiden Amerika Serikat.

Sejak menjadi seniman komersial, Warhol telah akrab dengan para pemilik galeri, oleh sebab itu dimana Ia ingin mengadakan pameran, selalu mendapat antusias tinggi bagi pemillik galeri. Beberapa galeri itu antara lain Hugo Gallery di New York yang diselenggarakan pada tahun 1954. Di Bodley Galery untuk pertama kalinya Warhol mengadakan pameran karya drawing-nya yang dikhususkan untuk dimuat disebuah penerbitan Boy Book, Di saat berpameran di Museum of Modern Art New York tahun 1956, Warhol menerima penghargaan dari Art Director Club Award atas karya advertasing 
untuk perusahaan sepatu Miller. Pameran terakhir dilakukan di Perancis tahun 1964, dan meneruskan profesi sebagai artis di Amerika di samping kesibukannya menjadi konsultan seni. Warhol juga mendirikan beberapa museum dan galeri di beberapa tempat di Amerika, yang tujuannya antara lain selain dimaksud sebagai tempat dokumentasi juga untuk pusat studi dan pengembangan para artis muda berbakat. Beberapa museum dan galeri itu antara lain: The Andy Warhol Museum di Pittsburgh, Warhol Foundation di New York, Andy Warhol Gallery di Gagosian Pensylvania (Honnef, 2006).

Ketenaran Warhol membuat dirinya mendapat julukan dari seseorang kritikus seni Museum of Modern, New York, Jeff Koons sebagai "Pope of Pop" (Walker, 1980). Pewacana kesenian Warhol terdiri dari para kritikus dan kurator, antara lain Joyce Hill Stoner ahli sejarah seni, pelukis dan direktur Preservation Studies Doctoral Program di Universitas Delaware. Selain itu masih ada lagi Gene E. Harris, Sebagai kurator karya-karya museum, dan Ted Ryan, kurator barang yang telah memilih printmaking Coca-Cola untuk dipamerkan. Mereka secara rutin melakukan pewacanaan kepada publik. Karya seni yang berkelanjutan adalah pekerjaan seniman yang berhasil "dicintai" para komponen art world. Untuk itu, ia harus menyentuh banyak orang, bekerja untuk banyak pihak.

\section{Kajian Relasi Tanda}

Kesenangan Warhol menggabungkan seni, kekayaan dan ketenaran membuat karyanya selalu bisa "dipakai" dan menjadi komoditas semua orang. Di dalam seni kapitalisme, segala bentuk hasil produk reproduksi keuntungan. Wujud komoditas sebenarnya ada didalam karakter sosial usaha kerja manusia yang tampak sebagai kerakteristik objekif, suatu sifat alami sosial hasil karya sendiri. Warhol berniat menjadikan seni itu bisnis yang indah untuk dinikmati, tapi juga bisa menghasilkan uang dan ketenaran untuknya. Perwujudan budaya pop art merupakan wujud dari ide-ide, gagasan, yang merupakan suatu aktivitas yang berpola dari manusia dalam masyarakat ataupun dapat berwujud sebagai benda hasil karya manusia. Warhol sebagai pribadi pada jamannya adalah seorang seniman yang mampu menciptakan mitos sebuah generasi.

Sebagai seniman profesional, dalam sosiologi seni aktivitas kreatif Warhol masuk dalam kelompok integrated professional, yang oleh Becker dikatakan: "have the technical abilities, social skills and conceptual apparatus" (1982: 228), selalu mempunyai kemampuan teknis, memiliki kecakapan sosial dan piranti koseptual yang memudahkan dalam berkesenian seniman profesional (caconic) juga harus bekerja secara pasti dan mengikuti konvensi dengan menyiapkan bahan, peralatan dan fasilitas ruang yang tersedia untuk memulai sebuah pekerjaan dan dengan kemampuan masyarakat untuk merespon secara tepat. Oleh Warhol dalam hal ini dapat ditujukkan melalui beberapa karyanya, dimana ia sebagai artis dalam untuk mewujudkan objeknya selalu berangkat dari konsepsi teorinya, kotak Brillo menyangkut hubungan antar ide satu dengan ide lainnya (secara kontekstual ingin menunjukan simbol-simbol produk konsumsi Amerika yaitu sabun dan grafis visual desainer Amerika), tentang apa dan bagaimana karya seni itu harus dibuat dan dikerjakan sehingga menjadi karya works of pop 
art yang "provoked" dan tetap bersandar pada nilai seni (Danton, 1973, 15).

$$
\text { Melalui kultur populer yang }
$$
dipresentasikan melalui idiom visual simbolik, Warhol mampu membuat mitos legendaris Amerikaisme yang mudah dikenal awam. Warhol tidak hanya piawai dalam menentukan sosok yang ditokoh-mitoskan akan tetapi pengetahuannya yang kuat dan dalam akan teknik dan pemilihan material cetak, membuat karya Warhol menjadi bagian instuisi filosofis yang luar biasa dan monumental (Danton, 1973, 376)

\section{PENUTUP}

Simpulan akhir, dari uraian di atas dapat ditarik asumsi bahwa bentuk kebudayaan $p o p$ art yang "dilakukan kini" dipastikan merupakan konsep yang telah mengalami "penyempurnaan" dari aktifitas kegiatan gaya atau budaya yang sebelumnya yang dilakukan oleh manusia, bahwa budaya pop art dapat diartikan sebagai sebuah pandangan hidup dari sebuah komunitas atau kelompok menjadi gaya angkatan baru dan umumnya menjadi semacam bentuk counter-culture. Sebuah gaya yang dimunculkan kembali tidak serta merta sama persis, artinya terdapat kecenderungan yang berbeda di balik pengulangan tersebut. Budaya pop art adalah suatu reaksi terhadap perubahan dan merupakan ekspresi untuk menyikapi perubahan tersebut. Warhol sebagai penerus dari para penggagas budaya pop art para pendahulunya, telah berhasil memberi spirit jaman itu. He is now the pioneer of the real spirit of the age!

\section{DAFTAR PUSTAKA}

[1] Barker, C. (2005). Cultural Studies Teori dan Praktek. Yogyakarta: Bentang.
[2] Berger, A. A. (2005). Tanda-tanda Dalam Kebudayaan Kontempore. Yogyakarta: Tiara Wacana.

[3] Bockris, V. (1989). The Life and Death of Andy Warhol. New York: Bantam Books.

[4] Britannica. (2016). Encyclopædia Britannica. Britannica.

[5] Croce, B. (1965). Aesthetic as Science of Expression and General Linguistic. , New York: The Noonday Press.

[6] Danesi, Marcel, \& Peron. (2004). Pesan, Tanda, dan Makna: Buku Teks Dasar Mengenai Semoitika dan Teori Komunikasi. Yogyakarta: Jalasutra.

[7] Hamilton, R. (2002). Pop Art Styles, Schools and Movements. London: Thompson \& Hudson.

[8] Hartley, J. (2010). Communication,Culture, and Media Studies: Konsep Kunci. Yogyakarta: Jalasutra.

[9] Honnef, K. (2006). Warhol. Koln: Tascen.

[10] Lodding, K. N. (1983). Iconic Interfacin. Computer Graphics and Applications, 4(12).

[11] Merapendra, D. (n.d.). Estetika Thomas Aquinas.

[12] Name, N. (n.d.). A Symposium on Pop Art,. Arts Magazine.

[13] Radzinowkez, D. (2001). Art Form Impressionsm to the Internet. Munich: Prestel Verlag.

[14] Robert Atkins. (1990). Art Speak. New York: Art Laison Inc,.

[15] Rusbiantoro, D. (2008). General MTV. Yogyakarta: Jalasutra.

[16] Walker, J. A. (1980). Art in the Age of Mass Media. London: Pluto Press.

[17] Zolberg, V. L. (1990). Constructing a Sociology of The Arts,. London: Cambridge University Press. 